\title{
Risk Assessment of Power Generated from a Wind Turbine in Different Climate Cities in Indonesia
}

\author{
Irvan Lumban Gaol, and Charles O. P. Marpaung*
}

\begin{abstract}
In this paper, a risk analysis based on Monte Carlo Simulation has been used to examine the power generated from a wind turbine. There are five cities are selected based on the wind speed to be examined the power density generated from the wind turbine. The cities are Kupang, Tanjung Pinang, Krinci, Kotabaru, and Pontianak. Among the five cities, Kupang has the highest wind speed, while Pontianak has the lowest wind speed. In this study, the wind speed is assumed to be an unspecified parameter or a random variable. The Monte Carlo Simulation is run by using a software @ RISK. The results show that the mean of power density generated from the wind turbine is found 171.23, 113.97, 71.28, 28.67, and 12.49 W/m² for Kupang, Tanjung Pinang, Krinci, Kotabaru, and Pontianak respectively. The width of the confidence interval with the level of probability $90 \%$ is 110.30 , 75.00, 69.10, 19.64, and 7.34 W/m² for Kupang, Tanjung Pinang, Krinci, Kotabaru, and Pontianak respectively. The upper bound of the confidence intervals are 230.1, 154.7, 113.3, 39.27, and 16.30 W/m² for Kupang, Tanjung Pinang, Krinci, Kotabaru, and Pontianak respectively, while the lower bounds are 119.8, 79.7, 44.2, and 19.63 W/m2 for Kupang, Tanjung Pinang, Krinci, Kotabaru, and Pontianak respectively. The probability of the power density will exceed the upper bound or will below the lower bound is $5 \%$.
\end{abstract}

Index Terms - Risk assessment, Monte Carlo Simulation, Wind turbine, Wind power density.

\section{INTRODUCTION}

$\mathrm{I}$ NVESTMENTS on new and renewable energy such as wind, solar, bioenergy, mini and micro-hydro, ocean and geothermal increase during the last few years in all countries in all over the world. The reasons are such that to reduce the $\mathrm{CO}_{2}$ emissions that cause global warming, to increase energy security in the countries, the cost of new and renewable energy decrease from year to year that makes the cost of producing electricity from the new and renewable energy almost approach the cost of producing electricity from conventional power plants such fossil fuel power plants [1], and to increase the share of renewable energy use in the country.

Manuscript received December 11, 2017; revised January 24, February 19, 2018; accepted March 8, 2018.

Irvan Lumban Gaol is a student at the Universitas Kristen Indonesia. His research of interest is in the area of variable renewable energy and power system planning. (e-mail: irvanmarbun28@gmail.com).

Charles O.P. Marpaung is with the Department of Electrical Engineering, Universitas Kristen Indonesia (UKI), Jakarta, Indonesia, (e-mail: cop.marpaung@gmail.com)

*Corresponding author.
In Indonesia, the energy potential of new and renewable energy in 2015 is 443.208 MW while the installed capacity is only 8.216 MW or around $1.9 \%$. The target of new and renewable energy Indonesia by 2025 is $23 \%$ of the total energy mix [2]. Of the totally new and renewable energy in Indonesia, the potential of wind power is significant, i.e., $60.647 \mathrm{MW}$, measured at wind speed greater $4 \mathrm{~m} / \mathrm{s}$. Although the energy potential of wind power is high, the installed capacity is only $3.1 \mathrm{MW}$ or less than $0.01 \%$ of the total wind energy potential in 2015. Hence, aggressive investment on wind energy would help to increase the share of new and renewable energy to the total energy mix in Indonesia. Unlike conventional power plants such as coal-based power plants, natural gas-based power plants and oil-based power plants, the investment on a wind turbine should be carefully done because there are many uncertainties on input variables to generate wind power from a wind turbine. The input uncertainties are related to climate parameters such as wind speed, temperature, and air pressure. All of these parameters affect the power generated from the wind turbine and difficult to predict and also different from one city to another city. Thus, one can never be sure how much power will be generated from a wind turbine. There are many studies has analyzed the power generated from a wind turbine. However, most of the studies used deterministic analysis, i.e., by taking the average value of the wind speed, temperature, and air pressure and do only one scenario. To the best of our knowledge, only a few studies have done risk analysis to estimate the power generated from a wind turbine. Risk analysis is much more informative for the energy planners to know the degree of attractiveness of a wind plant project because it is better and safe for them to make a decision based on a group of energy indicators calculated for these scenarios (risk analysis) than only one possible scenario (deterministic analysis). This study analyses the power generated from a wind turbine based on a risk analysis approach. In order to know the impacts of different climate on the power generated from a wind turbine, there are five cities in Indonesia are selected as case studies. The cities are categorized based on their wind speed, i.e., from high to low wind speed. The paper is organized as follows. A description of the methodology used in this study is presented in the next section followed by the input data and assumptions. The results and discussions are examined in the subsequent sections. Finally, the major findings of the study are summarized.

\section{Methodology}

A wind turbine obtains its energy power capturing a part of the kinetic energy of the wind that goes through the swept of its 
rotor and converts the force of the wind into a torque acting on the rotor blades. The power generated by the wind turbine is measured at the rotor blades and can be calculated as follows [3]:

$$
P=0.5 A_{r} C_{p} \rho V^{3}
$$

where:

$P=$ power generated [Watt]

$\rho=$ air density $\left[\mathrm{kg} / \mathrm{m}^{3}\right]$, which depends on the temperature and air pressure.

$A_{r}=$ rotor blades area $\left[\mathrm{m}^{2}\right]$

$C_{p}=$ aerodynamic power coefficient of the rotor blades

$V=$ wind speed $[\mathrm{m} / \mathrm{s}]$

If our purpose is to calculate the wind power density, Equation

(1) can be manipulated as follows:

$$
P / A=0.5 C_{p} \rho V^{3}
$$

where the left-hand side is called wind power density $\left(\mathrm{W} / \mathrm{m}^{2}\right)$. In this study, the wind power density is calculated rather than the wind power generated from the wind turbine. The wind power density is important for the design of the wind plant project, for example, to estimate the diameter of the blades and the capacity of the generator to be installed at the rotor blades of the wind turbine. The wind power density is also important to know the attractiveness of the wind plant project.

The Monte Carlo Simulation (also known as the Monte Carlo Method) is a computerized mathematical technique that allows people to account for risk in quantitative analysis and decision making. Monte Carlo Simulation furnishes the decision-maker with a range of possible outcomes and the probabilities they will occur for any choice of action. It shows the extreme possibilities - the outcomes of going for broke and for the most conservative decision-along with all possible consequences for middle-of-the-road decisions and assess the impact of risk, allowing for better decision making under uncertainty. In this study, the Monte Carlo Simulation (MCS) is used to analyze the risk of calculating the power density generated from a wind turbine. The Monte Carlo Simulation is used to overcome the variability of the input data which are uncertain with a reasonable degree of accuracy. The procedure of calculating the power density generated from a wind turbine by using the Monte Carlo Simulation (MCS) is depicted in Fig. 1 and can be explained as follows. A random number is used to produce a specific value from the cumulative probability curve of each uncertain variable or random variable. The cumulative probability curve is derived from the probability density function of the uncertain variable or random variable. The random number is generated by using a random number generator. The specific value is then introduced into the model (Eq. (2)) together with other variables (non-random variables) to obtain the power density generated from the wind turbine. The procedure is repeated several times to produce the corresponding probability distribution curve of the power density generated. By using probability distributions, variables can have different probabilities of different outcomes occurring. Probability distributions are a much more realistic way of describing uncertainty in variables of a risk analysis.
In this study, @ RISK software is used to run the Monte Carlo Simulation explained above. @ RISK is an add-in to Microsoft Excel that analyzes risk using Monte Carlo simulation. @RISK enables to simulate such models so that we can see a variety of scenarios that might occur, rather than a single "best guess" scenario. The output of @ RISK shows several graphs such as probability distribution function, cumulative distribution function, tornado graph which help us to do analysis in more detail on the power density generated from the wind turbine due to the uncertainties of the variables. @RISK shows virtually all possible outcomes for any situation-and tells how likely they are to occur. For example, we can know the probability that a value of power density falls in a certain confidence interval. This means we can judge which risks to take on and which ones to avoid. Further information about @ RISK can be seen in [4].

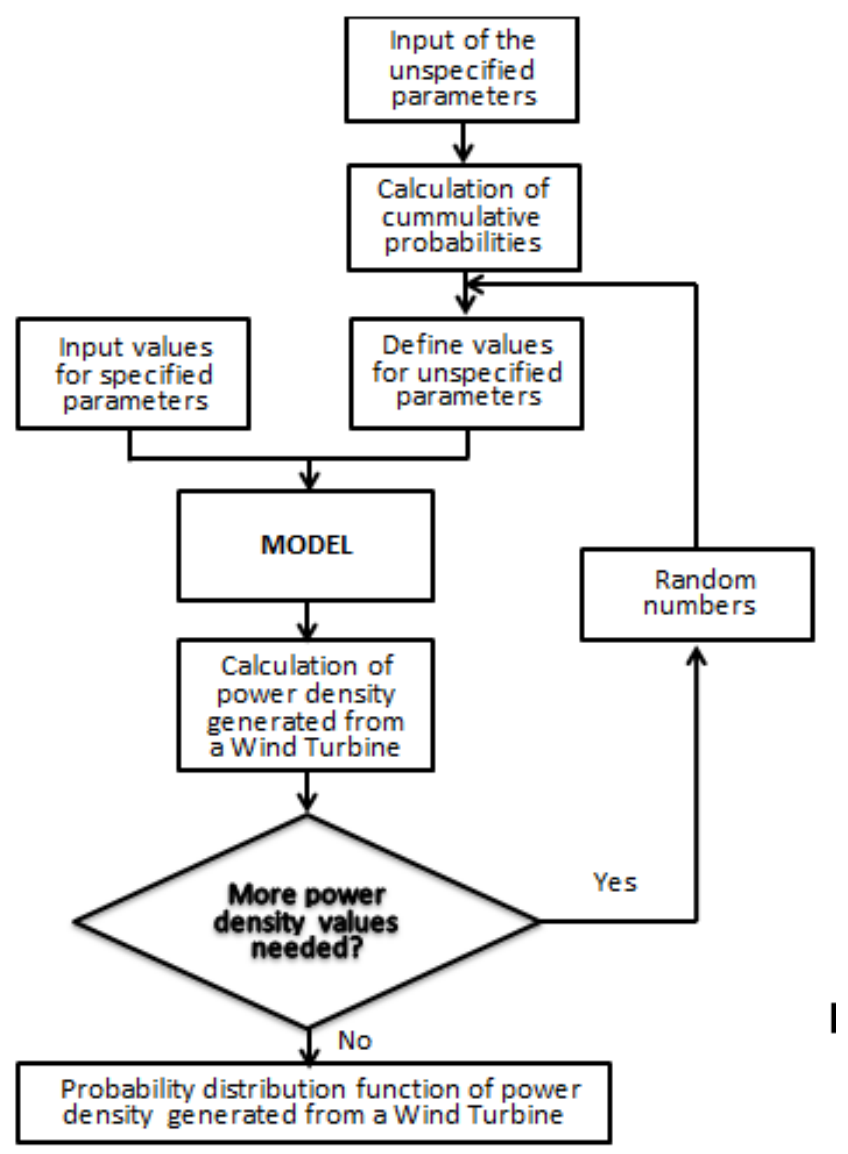

Fig. 1. Procedure for calculation of power density generated from a wind turbine using uncertain input data.

\section{INPUT DATA AND ASSUMPTIONS}

In this study, the values of $C_{p}$ and $\rho$ in Eq. (2) are specified. The values of $C_{p}$ is 0.59 [3] and assumed the same during the whole months in a year, while the values of $\rho$ are specified in monthly basis which depends on the temperature and air pressure.

The value of the wind speed in Eq. (2) is uncertain, or the wind speed is treated as a random variable. This type of "unspecified" data is handled with the help of statistical analysis. To do the statistical analysis, we should have the 
probability function of the wind speed. Actually, the wind speed follows the Weibull distribution function. However, since the parameters of the Weibull distribution function of the wind speed in all cities selected are not available, the probability density function of the wind speed is approached with the triangular function [5]. To simplify computations, a triangular distributions curve is assumed with the peak at the most probable value and zero probability below the minimum and above the maximum expected values. The parameter values (minimum-, maximum-, the most likely-values) of the triangular probability density function are calculated from the historical wind speed data. The original historical wind speed data are taken from [6]. The temperature and air pressure which is useful to calculate the air density $(\rho)$ are also taken from [6]. There are five cities are selected to estimate the wind power density generated from the wind turbine, they are Kupang, Tanjung Pinang, Kerinci, Kotabaru, dan Pontianak. The cities are categorized into five categories based on wind speed as shown in Table I.

TABLE I

WIND SPEED AT SELECTED CITIES

\begin{tabular}{lc}
\hline \multicolumn{1}{c}{ City } & Wind speed $(\mathbf{m} / \mathbf{s})$ \\
\hline Kupang & $6.6-7$ \\
Tanjung Pinang & $5.6-6.5$ \\
Kerinci & $4.6-5.5$ \\
Kotabaru & $3.6-4.6$ \\
Pontianak & $<3-3.5$ \\
\hline \hline Source: $[6]$
\end{tabular}

\section{RESULTS AND DISCUSSIONS}

The results of the simulation of the five cities are shown in Figs. 2, 3, 4, 5, ..., 10, 11 for the case of Kupang, Tanjung Pinang, Krinci, Kotabaru, and Pontianak respectively. Each city is represented by two types of function i.e., probability distribution function- and cumulative distribution function- of power density generated from the wind turbine. The probability distribution function are shown in Figs. 2, 4, .., 10, while the cumulative distribution function is shown in Figs. 3, 5, .., 11. Each probability density function shows the confidence interval where the power density generated from the wind turbine will locate in the interval with probability $90 \%$, while the cumulative distribution function shows the probability that the power density will take a value less than or equal to a quantity. Some quantities and their probabilities are shown in Tables II, III,..., VI for the case of Kupang, Tanjung Pinang, Krinci, Kotabaru, and Pontianak respectively. From the probability function, for example for the case of Kupang (Fig. 2), the probability that the wind power density generated from the wind turbine will lie between 119.8 and $230.1 \mathrm{~W} / \mathrm{m}^{2}$ within one year is $90 \%$. Figure 2 also shows that the probability that the wind power density exceed $230.1 \mathrm{~W} / \mathrm{m}^{2}$ is only $5 \%$. This indicates that the wind power density above $230.1 \mathrm{~W} / \mathrm{m}^{2}$ is almost unlikely to happen. The same figure also shows that the probability of the wind power density lower than $119.8 \mathrm{~W} / \mathrm{m}^{2}$ is $5 \%$, which indicates that the power density is almost impossible below $119.8 \mathrm{~W} / \mathrm{m}^{2}$. The confidence interval $[119.8,230.1] \mathrm{W} / \mathrm{m}^{2}$ as shown in Fig. 2 is important to quantify the project's degree of attractiveness. Sometimes, it is of interest also for the energy planners to increase the lower bound of the interval and would like to know the probability of the new interval. For this purpose, we can use the cumulative distribution function as shown in Fig. 3 and the values of the cumulative probability of each power density as shown in Table III for the case of Kupang. For example, for the case of Kupang, if we increase the lower bound of the interval to $142 \mathrm{~W} / \mathrm{m}^{2}$, what is now the probability that the wind power density generated from a wind turbine would fall in the interval $[142,230.1]$. From Fig. 3 and Table II we can calculate that the probability that the power density will fall in the interval [142, 230.1 ) is $70 \%$. Similar to Kupang, the confidence interval with the level of probability $90 \%$ for the case of Tanjung Pinang, Kerinci, Kotabaru, and Pontianak can be seen in Figs. 4, 6, 8, and 10 respectively.

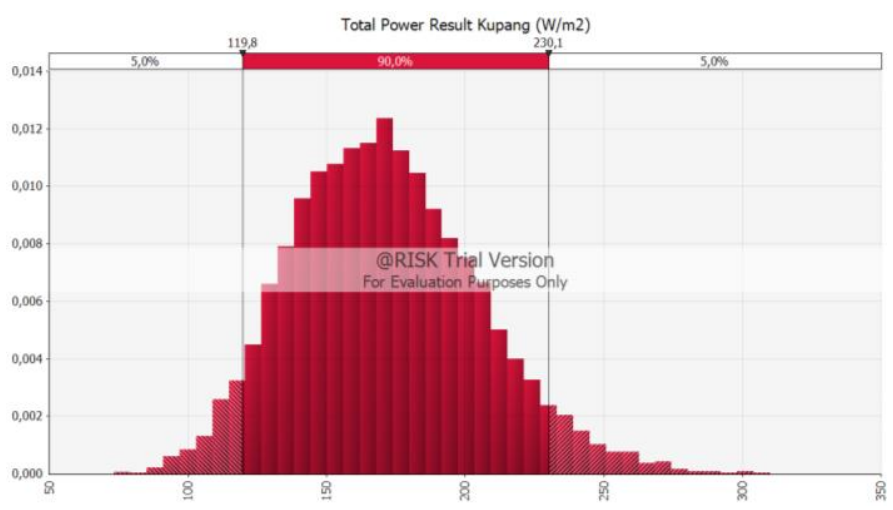

Fig. 2. The probability distribution function of power density generated from a wind turbine for Kupang.

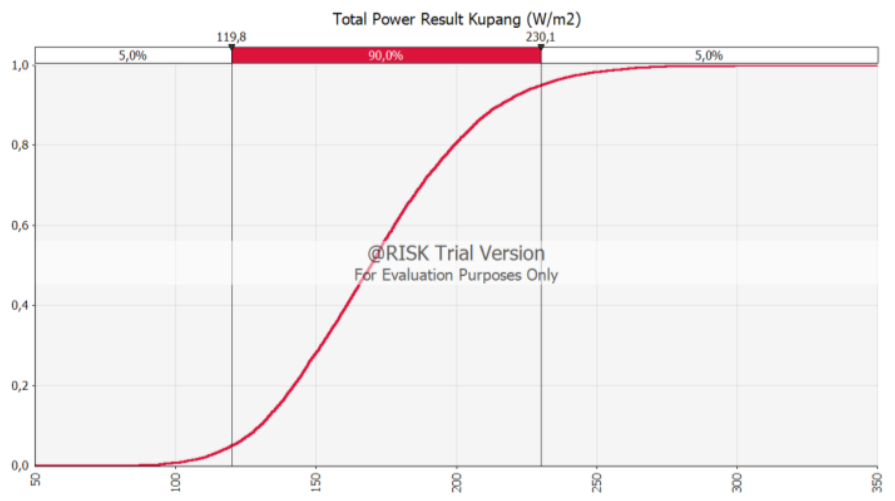

Fig. 3. The cumulative distribution function of power density generated from a wind turbine for Kupang.

The confidence intervals show that the probability that the power density will lie in the intervals is $90 \%$. Similar to Kupang, the probability will decrease if the lower bound of each confidence interval is increased, and the probability can be calculated by using Fig. 5 and Table III, Fig. 7 and Table IV, Fig. 9 and Table V, and Fig. 11 and Table VI for the case of Tanjung Pinang, Kerinci, Kotabaru, and Pontianak respectively. If the upper bound of the confidence intervals of the other cities is increased (see Figs. 4, 6, 8, and 10 for the case of Tanjung Pinang, Kerinci, Kotabaru, and Pontianak respectively), the probability of the new interval would not increase much. This is because the probability of the power density above the upper bound of the confidence intervals of the cities is only $5 \%$. The 
probability of the power density below the lower bound of the confidence interval of Tanjung Pinang, Kerinci, Kotabaru, and Pontianak as shown in Figs. 4, 6, 8, and 10 respectively are also $5 \%$, which indicates that the power density generated from the wind turbine under the lower bound of each of the confidence intervals are almost impossible.

TABLE II

VALUES OF CUMULATIVE DISTRIBUTION FUNCTION OF SELECTED VALUES OF POWER DENSITY FOR KUPANG

\begin{tabular}{cc|cc}
\hline \hline $\begin{array}{c}\mathrm{x}: \\
\text { Power } \\
\text { density } \\
\left(\mathrm{W} / \mathrm{m}^{2}\right)\end{array}$ & $\begin{array}{c}\mathrm{F}(\mathrm{x}): \\
\text { Value of cumulative } \\
\text { distribution function } \\
(\%)\end{array}$ & $\begin{array}{c}\mathrm{x}: \\
\text { Power } \\
\text { density } \\
\left(\mathrm{W} / \mathrm{m}^{2}\right)\end{array}$ & $\begin{array}{c}\mathrm{F}(\mathrm{x}): \\
\text { Value of cumulative } \\
\text { distribution function } \\
(\%)\end{array}$ \\
\hline 102.48 & 1 & 151.66 & 30 \\
119.80 & 5 & 156.36 & 35 \\
130.00 & 10 & 160.78 & 40 \\
136.43 & 15 & 165.09 & 45 \\
142.00 & 20 & 169.52 & 50 \\
146.85 & 25 & 173.50 & 55 \\
\hline \hline
\end{tabular}

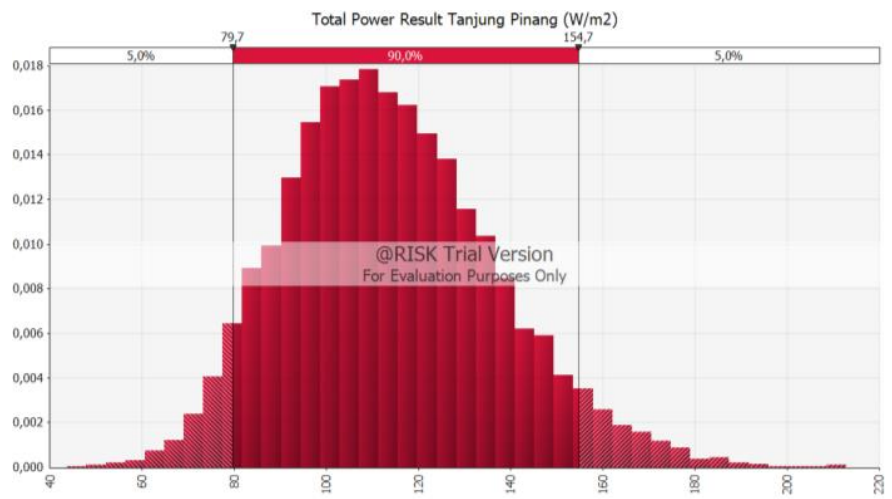

Fig. 4. The probability distribution function of power density generated from a wind turbine for Tanjung Pinang.

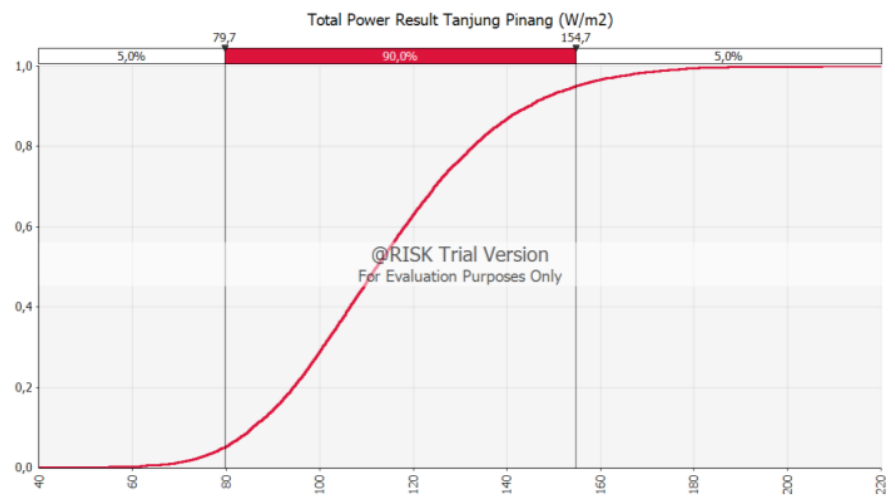

Fig. 5. The cumulative distribution function of power density generated from a wind turbine for Tanjung Pinang.

Table VII shows the average wind speed, mean-, confidence intervals, and width of confidence interval- of power density generated from the wind turbine at selected cities. The table shows that the width of the confidence interval increases with the increase of the wind speed. This is because the range of the wind speed (the difference between the highest and the lowest wind speed) at the city with higher wind speed is higher than that at the city with lower wind speed.
This is because the characteristic of the wind speed of the five cities considered in this study shows that the higher the wind speed, the higher the variety of wind speed.

TABLE III

VALUES OF THE CUMULATIVE DISTRIBUTION FUNCTION OF SELECTED VALUES OF POWER DENSITY FOR TANJUNG PINANG

\begin{tabular}{cc|cc}
\hline \hline $\begin{array}{c}\mathrm{x}: \\
\text { Power } \\
\text { density } \\
\left(\mathrm{W} / \mathrm{m}^{2}\right)\end{array}$ & $\begin{array}{c}\mathrm{F}(\mathrm{x}): \\
\text { Value of cumulative } \\
\text { distribution function } \\
(\%)\end{array}$ & $\begin{array}{c}\mathrm{x}: \\
\text { Power } \\
\text { density } \\
\left(\mathrm{W} / \mathrm{m}^{2}\right)\end{array}$ & $\begin{array}{c}\mathrm{F}(\mathrm{x}): \\
\text { Value of cumulative } \\
\text { distribution function } \\
(\%)\end{array}$ \\
\hline 68.63 & 1 & 100.58 & 30 \\
79.67 & 5 & 103.62 & 35 \\
85.63 & 10 & 106.42 & 40 \\
90.55 & 15 & 109.40 & 45 \\
94.40 & 20 & 112.13 & 50 \\
97.68 & 25 & 115.11 & 55 \\
\hline \hline
\end{tabular}

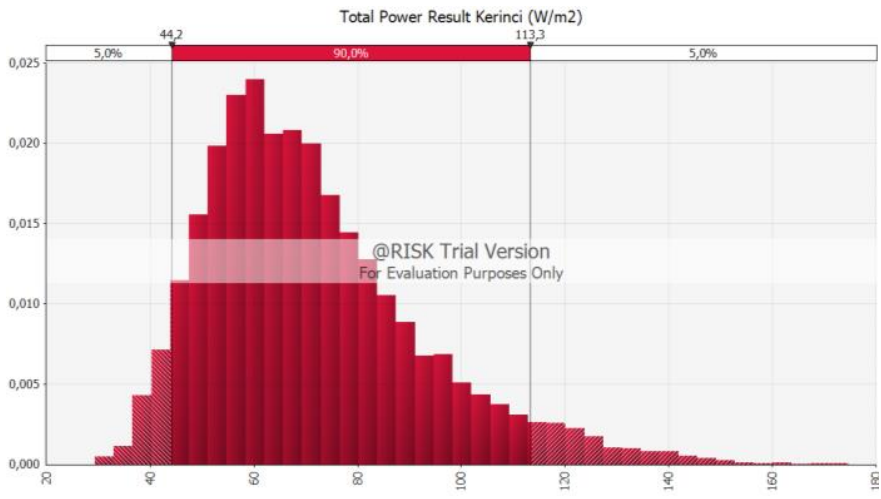

Fig. 6. The probability distribution function of power density generated from a wind turbine for Krinci.

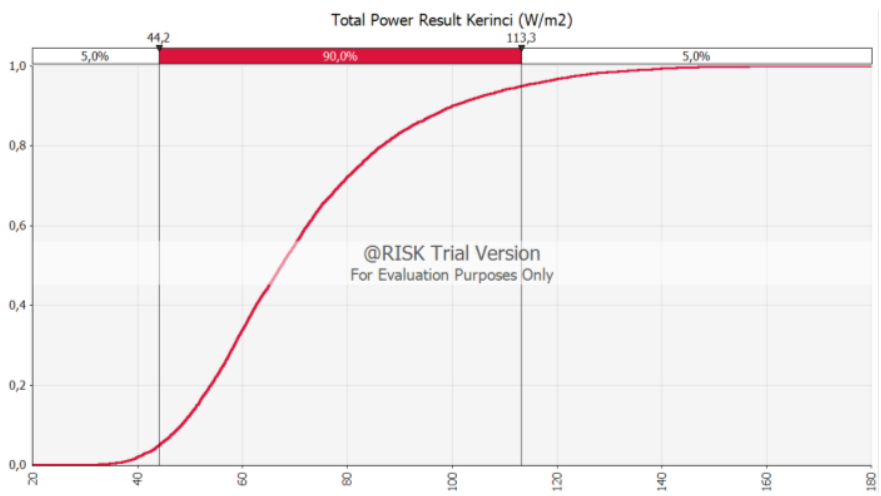

Fig. 7. The cumulative distribution function of power density generated from a wind turbine for Krinci.

TABLE IV

VALUES OF THE CUMULATIVE DISTRIBUTION FUNCTION OF SELECTED VALUES OF POWER DENSITY FOR KRINCI

\begin{tabular}{cc|cc}
\hline \hline $\begin{array}{c}\mathrm{X}: \\
\begin{array}{c}\text { Power } \\
\text { density } \\
\left(\mathrm{W} / \mathrm{m}^{2}\right)\end{array}\end{array}$ & $\begin{array}{c}\mathrm{F}(\mathrm{x}): \\
\text { Value of cumulative } \\
\text { distribution function } \\
(\%)\end{array}$ & $\begin{array}{c}\mathrm{x}: \\
\text { Power } \\
\text { density } \\
\left(\mathrm{W} / \mathrm{m}^{2}\right)\end{array}$ & $\begin{array}{c}\mathrm{F}(\mathrm{x}): \\
\text { Value of cumulative } \\
\text { distribution function } \\
(\%)\end{array}$ \\
\hline 38.02 & 1 & 58.38 & 30 \\
44.16 & 5 & 60.51 & 35 \\
48.30 & 10 & 62.57 & 40 \\
51.35 & 15 & 65.05 & 45 \\
53.97 & 20 & 67.45 & 50 \\
56.34 & 25 & 69.90 & 55 \\
\hline \hline
\end{tabular}




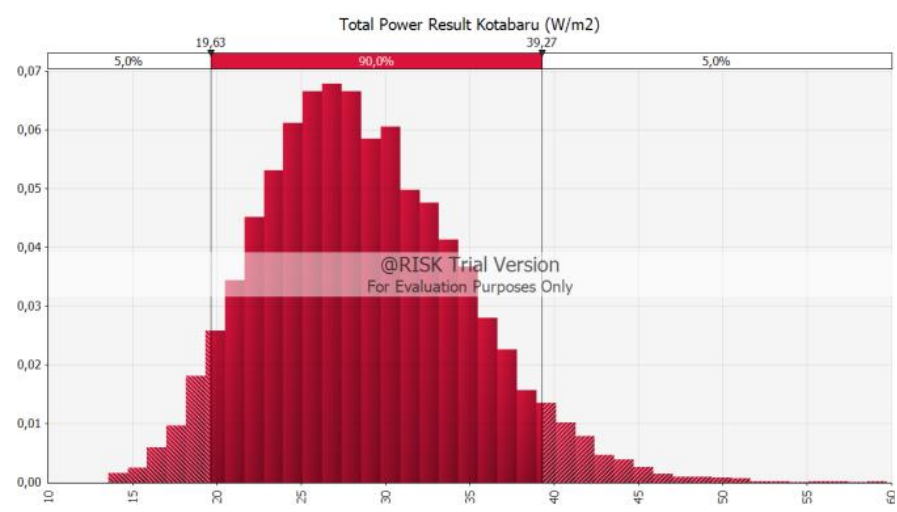

Fig. 8. The probability distribution function of power density generated from a wind turbine for Kotabaru.

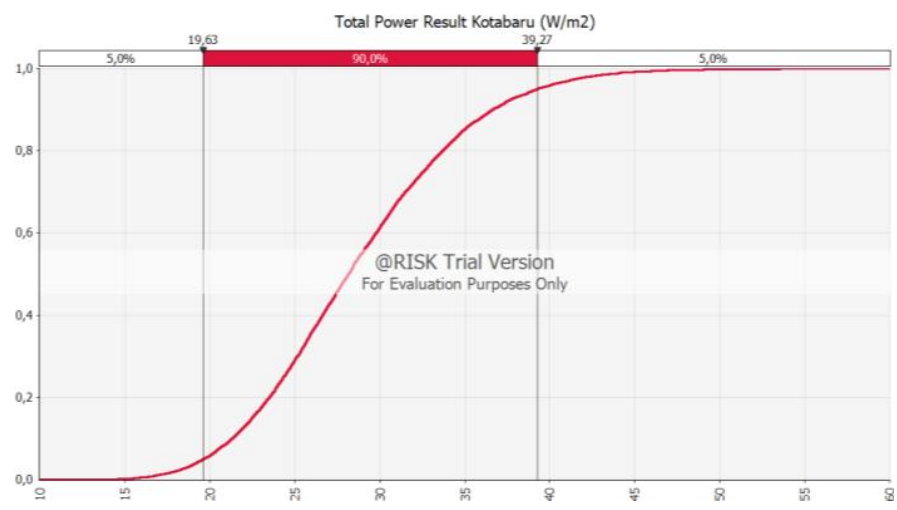

Fig. 9. The cumulative distribution function of power density generated from a wind turbine for Kotabaru.

TABLE V

VALUES OF THE CUMULATIVE DISTRIBUTION FUNCTION OF SELECTED VALUES OF POWER DENSITY FOR KOTABARU

\begin{tabular}{cc|cc}
\hline \hline $\begin{array}{c}\mathrm{x}: \\
\text { Power } \\
\text { density } \\
\left(\mathrm{W} / \mathrm{m}^{2}\right)\end{array}$ & $\begin{array}{c}\mathrm{F}(\mathrm{x}): \\
\text { Value of cumulative } \\
\text { distribution function } \\
(\%)\end{array}$ & $\begin{array}{c}\mathrm{x}: \\
\text { Power } \\
\text { density } \\
\left(\mathrm{W} / \mathrm{m}^{2}\right)\end{array}$ & $\begin{array}{c}\mathrm{F}(\mathrm{x}): \\
\text { Value of cumulative } \\
\text { distribution function } \\
(\%)\end{array}$ \\
\hline 16.87 & 1 & 25.16 & 30 \\
19.63 & 5 & 25.88 & 35 \\
21.32 & 10 & 26.64 & 40 \\
22.48 & 15 & 27.39 & 45 \\
23.50 & 20 & 28.18 & 50 \\
24.36 & 25 & 28.94 & 55 \\
\hline \hline
\end{tabular}

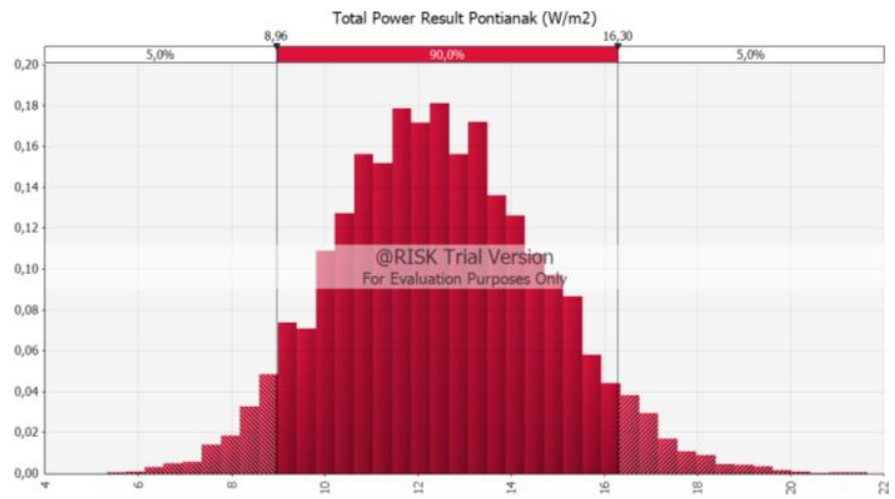

Fig. 10. The probability distribution function of power density generated from a wind turbine for Pontianak.

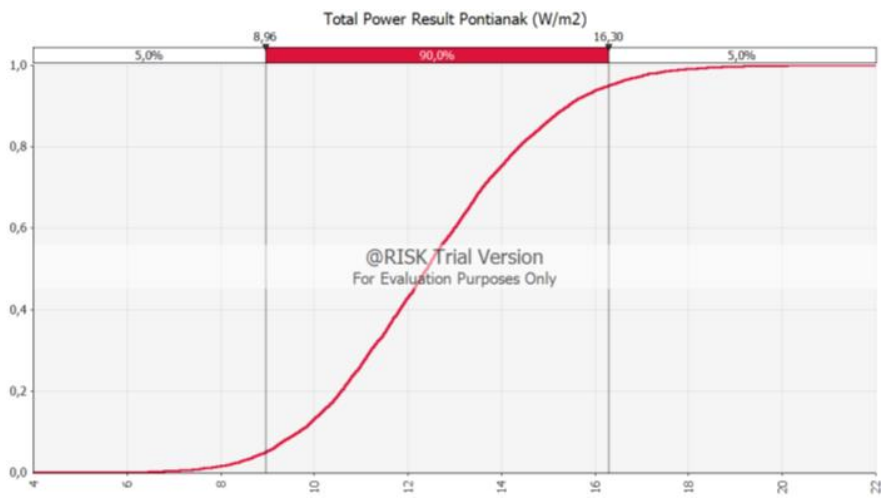

Fig. 11. The cumulative distribution function of power density generated from a wind turbine for Pontianak.

TABLE VI

VALUES OF THE CUMULATIVE DISTRIBUTION FUNCTION OF SELECTED VALUES

\begin{tabular}{|c|c|c|c|}
\hline $\begin{array}{c}\mathrm{x}: \\
\text { Power } \\
\text { density } \\
\left(\mathrm{W} / \mathrm{m}^{2}\right)\end{array}$ & $\begin{array}{c}\mathrm{F}(\mathrm{x}) \text { : } \\
\text { Value of cumulative } \\
\text { distribution function } \\
(\%)\end{array}$ & $\begin{array}{c}\mathrm{x}: \\
\text { Power } \\
\text { density } \\
\left(\mathrm{W} / \mathrm{m}^{2}\right) \\
\end{array}$ & $\begin{array}{c}\mathrm{F}(\mathrm{x}) \text { : } \\
\text { Value of cumulative } \\
\text { distribution function } \\
(\%)\end{array}$ \\
\hline 7.62 & 1 & 11.30 & 30 \\
\hline 8.96 & 5 & 11.54 & 35 \\
\hline 9.66 & 10 & 11.83 & 40 \\
\hline 10.18 & 15 & 12.13 & 45 \\
\hline 10.57 & 20 & 12.40 & 50 \\
\hline 10.91 & 25 & 12.67 & 55 \\
\hline
\end{tabular}

TABLE VII

AVERAGE WIND SPEED, MEAN- AND CONFIDENCE INTERVAL- OF POWER DENSITY GENERATED FROM A WIND TURBINE AT SELECTED CITIES

\begin{tabular}{lcccc}
\hline \hline City & $\begin{array}{c}\text { Average } \\
\text { wind } \\
\text { speed } \\
(\mathrm{m} / \mathrm{s})\end{array}$ & $\begin{array}{c}\text { Mean of } \\
\text { power } \\
\text { density } \\
\text { generated } \\
\left(\mathrm{W} / \mathrm{m}^{2}\right)\end{array}$ & $\begin{array}{c}\text { The confidence } \\
\text { interval of } \\
\text { power density } \\
\text { generated with } \\
\text { a level of } \\
\text { probability of } \\
90 \%\left(\mathrm{~W} / \mathrm{m}^{2}\right)\end{array}$ & $\begin{array}{c}\text { The width } \\
\text { of the } \\
\text { confidence } \\
\text { interval of } \\
\text { power } \\
\text { density } \\
\text { generated } \\
\left(\mathrm{W} / \mathrm{m}^{2}\right)\end{array}$ \\
\hline Kupang & 7.31 & 171.23 & {$[119.8,230.1]$} & 110.30 \\
Tanjung Pinang & 6.15 & 113.97 & {$[79.7,154.7]$} & 75.00 \\
Kerinci & 4.92 & 71.28 & {$[44.2,113.3]$} & 69.10 \\
Kotabaru & 3.81 & 28.67 & {$[19.63,39.27]$} & 19.64 \\
Pontianak & 3.36 & 12.49 & {$[8.96,16.30]$} & 7.34 \\
\hline \hline
\end{tabular}

\section{CONCLUSION AND FINAL REMARKS}

This study assesses the risk of power density generated from a wind turbine in five different climate cities by using the Monte Carlo Simulation approach. The cities are selected based on the level of the wind speed, i.e., from the highest to the lowest wind speed. The cities are Kupang, Tanjung Pinang, Kerinci, Kota Baru and Pontianak. Since the wind speed is uncertain in all cities, so the wind speed is treated a random variable, and the probability density function of the wind speed is approached with the triangular density function. The software used to run the Monte Carlo Simulation is @ RISK. The results show that the mean of power density generated from the wind turbine in Kupang, Tanjung Pinang, Kerinci, Kota Baru and Pontianak are $171.23,113.97,71.28,28.67$, and $12.49 \mathrm{~W} / \mathrm{m}^{2}$ respectively. The 
confidence intervals of the power density generated from the wind turbine with level of probability $90 \%$ are [119.8, 230.1], [79.7, 154.7], [44.2, 113.3], [19.63, 39.27], and [8.96, 16.30] $\mathrm{W} / \mathrm{m}^{2}$ for Kupang, Tanjung Pinang, Kerinci, Kota Baru and Pontianak respectively. The probability of the power density exceeds the upper bound of the confidence interval of each city is $5 \%$, while the probability of the power density below the lower bound of the confidence interval of each city is also $5 \%$. The highest width of the confidence interval of the wind power density generated from the wind turbine with the level of probability $90 \%$ is at the city with the highest average wind speed, i.e. Kupang, and then followed by Tanjung Pinang, Kerinci, Kotabaru, and Pontianak. The width of the confidence interval depends on the variety of the speed of the wind. The higher the wind speed, the wider the confidence interval. The level of the probability of the confidence interval would affect the selection of the capacity of the generator to be installed at the rotor blade of the wind plant. The level of the probability of the confidence interval would also affect the attractiveness of the wind plant project. In this study, only one type of wind turbine is examined for the cities selected. The result would be different if different types of a wind turbine are studied in different cities with different wind speed.

\section{REFERENCES}

[1] El-Shimy, M.. (2017), Economics of Variable Renewable Sources for Electric Power Production., Saarbrücken: Lambert Academic Publishing.

[2] Kemenristekdikti 92017),"Rencana Umum Energi Nasional (RUEN) Peraturan Presiden Nomor 22 Tahun 2017".

[3] Salles, A.C.N., Melo, A.C.G., Legey, L.F.L. (2004) 'Risk analysis methodologies for financial evaluation of Wind Energy Power Generation Projects in the Brazillian System', $8^{\text {th }}$ International Conference on Probabilistic Methods Applied to Power Systems, Iowa State University, Ames, Iowa.
[4] Palisade Corporation (2018), Guide to using @Risk - Risk Analysis and Simulation Add-in for Microsoft Excel Version 7.6 Industrial, Palisade Corporation, Newfield, NY USA.

[5] Vafaeipour, M., Valizadeh, M. H., Rahbari, O., Eshkalag, M. K. (2014), Statistical analysis of wind and solar energy potential in Tehran, International Journal of Renewable Energy Research, Vol. 4, No. 1, pp. 233-239.

[6] Data Online BMKG 2017 [Online]. Available: http://dataonline.bmkg.go.id.

\section{BIOGRAPHIES}

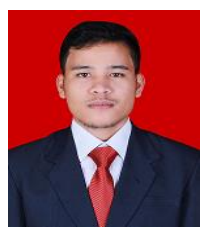

Irvan Lumban Gaol is a student of Electrical Engineering, Faculty of Engineering, the Universitas Kristen Indonesia. His research of interest is in the area of variable renewable energy and power system planning.

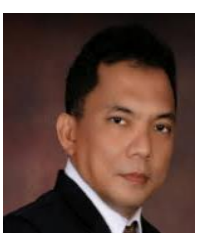

Charles O. P. Marpaung graduated from the Bandung Institute of Technology-Indonesia in 1986 with a B.Sc. degree in Electrical Engineering. He obtained his M.S. degree in Applied Statistics from the Bogor Agricultural University-Indonesia in 1990. His Ph.D. degree (1998) is in Energy Economics and Planning from the Asian Institute of Technology-Thailand. Charles O. P. Marpaung is a Full Professor in the Department of Electrical Engineering, Universitas Kristen Indonesia and he is now the Head of Institute for Research and Community Service at the university. He had been a Visiting Faculty at the Department of Electrical and Electronics Engineering, Sophia University, Tokyo-Japan and also at the Energy Field of Study of the Asian Institute of Technology from 2009-2013. His areas of interest are environmental and economic implications of utility planning and energy-economy modeling. He has authored several technical papers and reports in these areas and some have been published in international refereed journals, such as Energy Policy, Energy the International Journal, RERIC International Energy Journal, and International Journal of Global Energy Issues. He is also a reviewer of Energy Policy and Energy the International Journal. 